\title{
Development of antibacterial nanofibrous wound dressing and conceptual reaction mechanism to deactivate the viral protein by Nigella sativa extract
}

\author{
Md Abdus Shahid ${ }^{1}$ (D) Abdur Rahim ${ }^{2} \cdot$ Mohammad Asaduzzaman Chowdhury $^{3}$ (D) Mohammad Abul Kashem $^{4}$
}

Received: 28 May 2020 / Accepted: 14 December 2020 / Published online: 13 January 2021

(c) Institute of Korean Medicine, Kyung Hee University 2021

\begin{abstract}
Nigella sativa ( N. sativa) is extensively used as medicinal plant all over the world. It has the potential properties as the antiviral and antibacterial application. Its seed contain thymoquinone (TQ), thymohydroquinone (THQ), thymol (THY), p-cymene as major and other minor components. TQ and THQ exhibit broad spectrum of antimicrobial properties against the activity of bacteria, viruses, parasites, schistosoma and fungi. This work provides credence to the fabrication of antibacterial nanofibrous membrane by electrospinning machine from $N$. sativa extract with polyvinyl alcohol (PVA) solution for wound dressing. The morphology of the developed membrane is also characterized using scanning electron microscope. Fourier transform infrared spectroscopy (FTIR) data has been showed that the functional groups of N. sativa are present in the prepared PVA-N. sativa nanofibrous membrane and its antibacterial activity was investigated. The disk diffusion method has been used to evaluate the antibacterial activity of PVA-N. sativa nanofibrous membrane against Staphylococcus aureus (S. aureus) bacteria and the inhibition zone with a value of $10 \mathrm{~mm}$ is formed. Considering the inherent properties of $N$. sativa, a conceptual reaction mechanism has been proposed to deactivate the viral proteins by the action of TQ and THQ.
\end{abstract}

Keywords Nigella sativa $\cdot$ Electrospinning $\cdot$ Nanofibrous membrane $\cdot$ Staphylococcus aureus $\cdot$ Viral protein

\section{Introduction}

Nigella sativa is a famous and special plant that has been widely used in different cultures for many centuries (Saad et al. 2005; Mohammed and Babikir 2013). It is commonly known as black seed, posses several medicinal properties. In herbal medicine, this seed has been extensively reported to treat asthma, hypertension, gastric disorders,

Md Abdus Shahid

shahid@duet.ac.bd

1 Department of Textile Engineering, Dhaka University of Engineering and Technology (DUET), Gazipur 1707, Bangladesh

2 Department of Chemistry, College of Home Economics, Azimpur, Dhaka 1205, Bangladesh

3 Department of Mechanical Engineering, Dhaka University of Engineering and Technology (DUET), Gazipur 1707, Bangladesh

4 Department of Computer Science and Engineering, Dhaka University of Engineering and Technology (DUET), Gazipur 1707, Bangladesh liver disorders, immune disorders, cancer, neurological disorders, and many other health conditions (Majeed et al. 2020; Mahmoud and Abdelraazek 2019). From the religious background, it is called the miracle curative herb for all ailments, except the death (Mahboubi 2018). Enhancement of immunity system in human body, $N$. sativa extract has inhibitory response on the human immune deficiency virus protease but the active principle happens for this activity was not determined. $N$. sativa seed and its oil are used as a wound healing in farm animals (Aljabre et al. 2015). The novel coronavirus 2019 (2019-nCoV), officially named severe acute respiratory syndrome coronavirus 2 (SARS-CoV-2), is a newly emerged human infectious coronavirus that contains four proteins (Lai et al. 2020). Many different treatment options have been suggested and some older drugs are used to treat patients even though much more works are demanded. The supportive treatment, including oxygen therapy, conservation fluid management, and the use of broad-spectrum antibiotics to cover secondary bacterial infection remains to be the most important management (Huang et al. 2020). Considering the limitations of treatments of virus with 
existing and new medicine, this study suggested the possibility of antiviral medicine from $N$. sativa components. $N$. sativa seeds contain $36-38 \%$ fixed oils, proteins, alkaloids, saponin and 0.4-2.5\% essential oil. Many components of essential oil were characterized but the major ones were TQ (27.8-57.0\%), p-cymene (7.1-15.5\%), carvacrol $(5.8-11.6 \%), \mathrm{t}$-anethole $(0.25-2.3 \%)$, 4-terpineol (2.0-6.6\%) and longifoline (1.0-8.0\%). TQ can readily dimerizes to form DTQ (Ali and Blunden 2003). Recently, clinical and experimental studies have demonstrated many therapeutic effects of TQ including immunomodulatory, anti-inflammatory, antitumor and antimicrobial (Ahmad et al. 2013; Al-Mufarrej 2014; Azeem et al. 2014). Several bioactive compounds from the seed of $N$. sativa have been reported in the literature; among those the most important bioactive ones are TQs. Due to a vast number of biological targets and virtually no side effects, $N$. sativa has achieved the potential therapeutic interest to cure immunosuppressive viral diseases. The essential oil composition $(0.4-0.45 \%)$ reported in various studies represented about forty different compounds, amongst the abundantly constituents identified are trans-anethole, $p$-cymene, limonene, carvone, $\alpha$-thujene, TQ,THQ, DTQ, carvacrol, and $\beta$-pinene with various concentrations (Ainane et al. 2014; Benkaci-Ali et al. 2013; Tohumiari 2017). Nanofibrous membrane have been produced by electrospinning technique from natural, modified natural and synthetic polymers has drawn a lot of attention for few years for their applications in biomedical fields like wound dressing, tissue engineering, filtration media and drug delivery. Natural polymers have drawn much attraction due to their excellent properties like biocompatibility, biodegradation, low toxicity, high porosity, light weight and most prominently large surface area (Guarino and Ambrosio 2018). Usually metal nanoparticles are incorporated to offer antibacterial properties in the nanofibrous materials. Due to the harmful effects of nanoparticles and synthetic antibiotics on the environment, human health and/or bacteria resistance issues, the use of natural antimicrobial compounds are still demanding because of keeping safe sustainable environment and less prone to create resistant bacteria (Abdullah et al. 2014; Agarwal et al. 2008; Venugopal et al. 2008). Hence, the development of nanofibrous membrane through electrospinning technique embedding the component of $N$. sativa like natural biocide has a great importance in this field. This study investigates the antibacterial efficacy of the nanomembrane developed from the mixture of PVA and $N$. sativa extract to nullify the use of conventional metal nanoparticles into such type of antibacterial nano-structures (Shahid et al. 2020; Ali and Shahid 2019; Ali et al. 2019). To the best of our knowledge, there is no details explanation of reaction mechanism to deactivate the virus and their consequences by the components of $N$. sativa seed. In the present study, a theoretical mechanism has been proposed to deactivate the virus. This concept can be used in future to make a drug against virus for survival of human life of the world.

\section{Method}

\section{Material}

Seeds of N. sativa were collected from the market of Gazipur city, Bangladesh. PVA (molecular weight 115,000, degree of polymerization $170-800$, viscosity $26-32 \mathrm{cps}, 99 \%$ hydrolyzed granules was sourced from Loba chemical, India and absolute methanol of $99 \%$ purity was sourced from Merck, Germany. All of the chemicals were used without further purification or modification. Viral protein is considered to develop the conceptual reaction mechanism by the action of TQ and THQ.

\section{Fabrication of PVA-N. sativa Nanofibrous Membrane}

The seeds of $N$. sativa were washed thoroughly with mineral water and grinded to reduce its size and then immersed into methanol of sigma-aldrich at the ratio of $1: 2(N$. sativa: methanol) for $8 \mathrm{~h}$. This solution was filtered through a quadruple layer of nylon mesh fabric two times and it was magnetically stirred at $70{ }^{\circ} \mathrm{C}$ for $8 \mathrm{~h}$ in order to obtain the $N$. sativa extracted solution. On the other hand, solution of $10 \%$ (w/v) PVA was prepared at $70{ }^{\circ} \mathrm{C}$ by dissolving the PVA grains in 50\% aqueous acetic acid solution. Final solution to feed into the electrospinning machine was made by adding $17 \mathrm{~g}$ of $N$. sativa extract to $30 \mathrm{~mL}$ of PVA solution and stirred until a homogeneous solution was obtained. Electrospinning machine of model: TL-01, Tong Li tech. China was used to fabricate the nanofibrous membrane by optimizing the process parameters of voltage, pressure, heater power, collector distance under ambient condition of $65 \%$ relative humidity and $27{ }^{\circ} \mathrm{C}$ temperature. The parameters were optimized by trial and error method at voltage of $-12.3 \mathrm{kV},+23 \mathrm{kV}$; heater power of $0.45 \mathrm{~kW}$; collector distance of $15 \mathrm{~cm}$ and flow rate of $1.5 \mathrm{~mL}$ to fabricate the PVA- $N$. sativa nanofibrous membrane.

\section{Characterization of PVA-N. sativa nanofibrous membrane}

Scanning electron microscopy (SEM) of model: SU 1510, Hitachi, Japan was used to observe the morphology of developed sample at $5 \mathrm{kV}$ and $2 \mathrm{kX}$ magnification. FTIR (IR Prestige 21, Shimadzu Corporation, Japan) was used to analyze the spectra of the sample at $4000-698 \mathrm{~cm}^{-1}$ resolution. Antibacterial activity of the sample was studied using 
disc diffusion method $\left(1.5 \times 10^{5} \mathrm{CFU} / \mathrm{mL}\right)$ against $S$. aureus bacteria as it is more responsible for wound infection and zone of inhibition (ZOI) was measured and compared with PVA nanofibrous membrane (Shahid et al. 2020).

\section{Results}

\section{SEM, FTIR and antibacterial test analysis}

The image of SEM is shown in Fig. 1. It reflects the formation of nanofibers having an average diameter of $215 \mathrm{~nm}$ and shows tiny pores in it. The presence of tiny pores in wound dressing materials is effective because diffusion

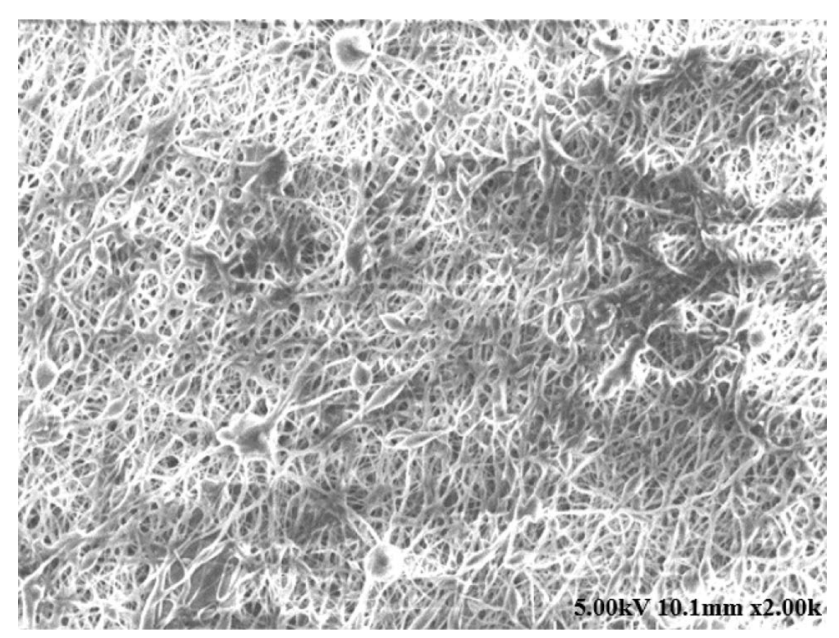

Fig. 1 Morphology of PVA-N. sativa nanofibrous SEM image at $10 \mathrm{kV}$ and $5 \mathrm{kX}$ magnification and permeability of oxygen from air to skin is provided through tiny pores. The existence of such type pores does not only allow air ventilation but also restrict the penetration of bacteria in the wound area (Liu et al. 2010; Yang et al. 2009).

The FTIR spectra of PVA and PVA- $N$. sativa nanofibrous membrane are shown in Fig. 2. The characteristic pecks of PVA- $N$. sativa nanofibrous membrane in FTIR spectra have been found at $3009 \mathrm{~cm}^{-1}(\mathrm{C}-\mathrm{H}$ stretching of vinyl group), $2927 \mathrm{~cm}^{-1}$ (C-H stretching), $2858 \mathrm{~cm}^{-1}$ (C-H stretching of aliphatic group), $1716 \mathrm{~cm}^{-1}(\mathrm{C}=\mathrm{O}$ stretching for ester and ketone groups), $1463 \mathrm{~cm}^{-1}(\mathrm{C}-\mathrm{H}$ absorption scissoring) and $1087 \mathrm{~cm}^{-1}$ (C-O-C stretching) (Mansur et al. 2008). In FTIR analysis, various components and functional groups like $\mathrm{C}=\mathrm{O}, \mathrm{C}-\mathrm{O}, \mathrm{CH}_{3}, \mathrm{CH}_{2}$ chemical constituents are present in PVA- $N$. sativa nanofibrous membrane. FTIR data also showed the presence of $\mathrm{O}-\mathrm{H}, \mathrm{C}=\mathrm{O}$ and $\mathrm{C}-\mathrm{O}$ for acetate group in PVA nanofibrous membrane. These results indicate the presence of $N$. sativa components in PVA- $N$. sativa nanofibrous membrane.

Antibacterial activities of developed samples were investigated by using disc diffusion method against $S$. aureus bacteria and ZOI was measured. The ZOI of PVA and PVA- $N$. sativa nanofibrous membrane are shown in Fig. 3. ZOI of $10 \mathrm{~mm}$ is formed in PVA- $N$. sativa nanofibrous membrane whereas there is no inhibition zone in PVA nanofibrous membrane against $S$. aureus bacteria. The $S$. aureus Gram-positive bacteria is highly susceptible to TQ and THQ (Mohammed et al. 2019). This result is similar with literatures (Khan 2018; Park et al. 2015) that stated the mechanism of killing bacteria with components of $N$. sativa.
Fig. 2 FTIR spectra of PVA and PVA- $N$. sativa membrane scanned at $4000-698 \mathrm{~cm}^{-1}$

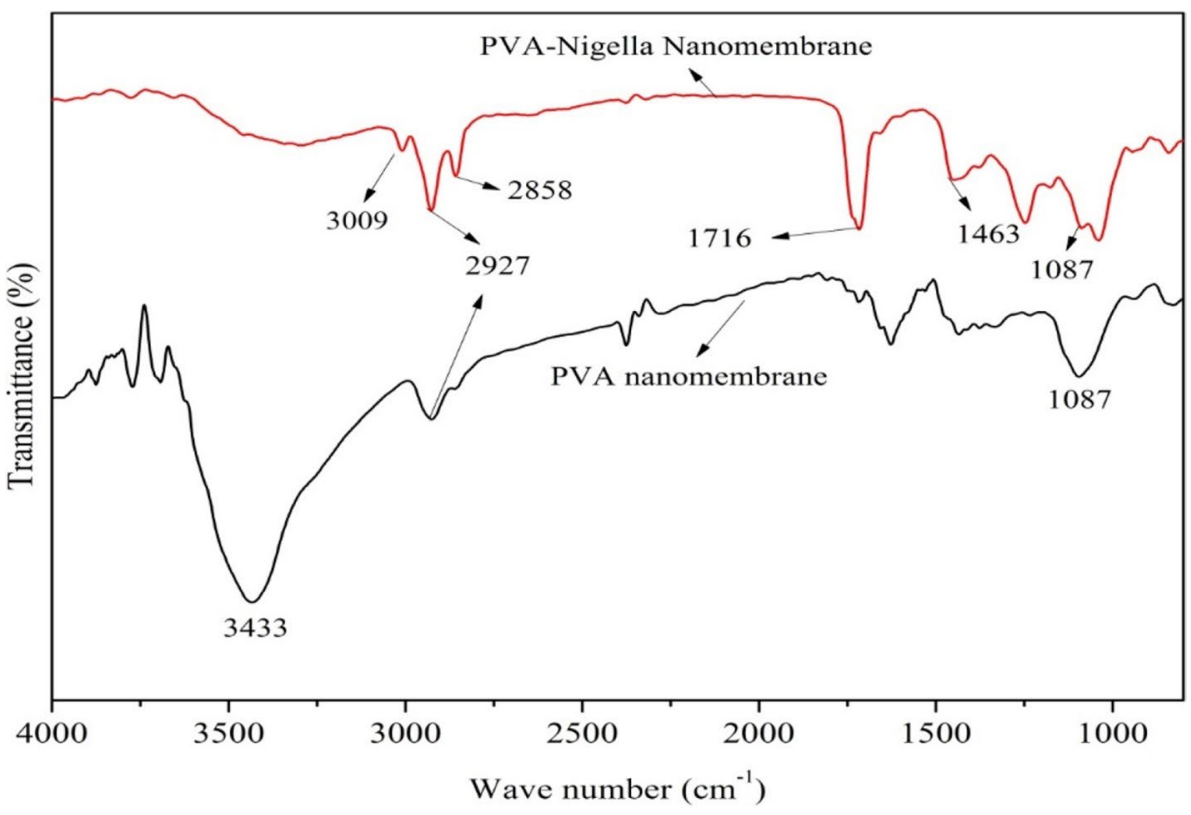


Fig. 3 Zone of inhibition formation in a PVA and b PVA- $N$. sativa nanofibrous membrane

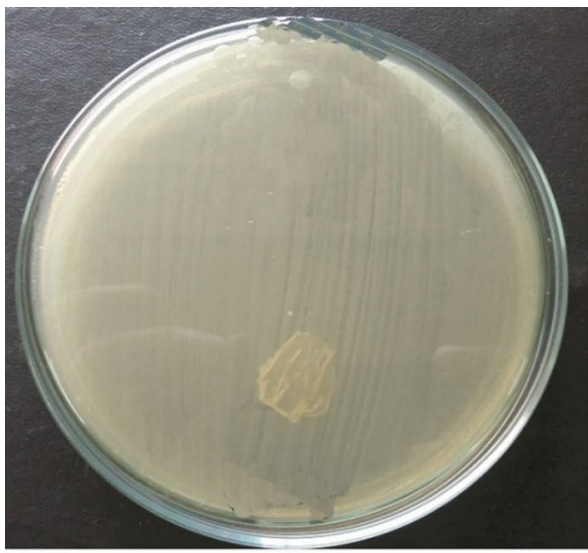

(a)

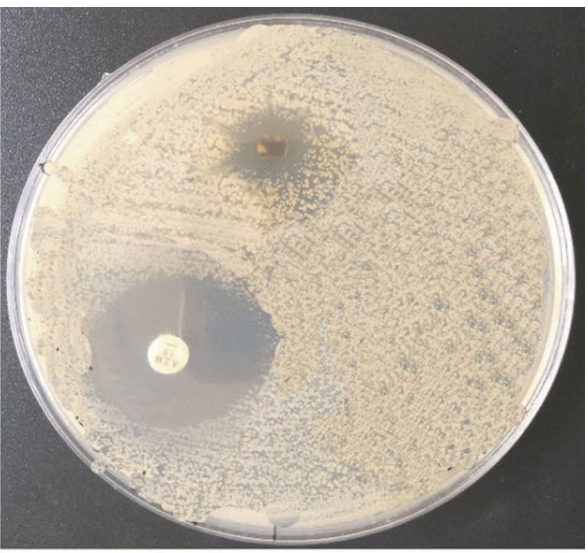

(b)

\section{Deactivation mechanism of viral proteins}

N. sativa contains active ingredients like TQ, THQ, DTQ, THY, p-cymene and other minor components. Chemical structures of the main components are given in Fig. 4.

Some recent interesting research findings of $N$. sativa and its components are provided in Table 1.

TQ is an active ingredient which is widely used as medicinal compound isolated from $N$. sativa. This component of $N$. sativa will be a promising agent to deactivate the virus. Virus consists of different types of proteins (Lodish et al.
2000; Schoeman and Fielding 2019; Seebach et al. 2004; Shereen et al. 2020). If we can modify or damage the proteins by active components of $N$. sativa consequently virus will be deactivated. For clear understanding, we consider TQ and THQ components for the reaction with viral proteins. TQ may modify/damage the proteins. A proposed mechanism for the reaction involved is presented in Fig. 5 (Vaughn et al. 2013; Kim et al. 2012; Mohammed et al. 2019; Armutcu et al. 2018; Kundu et al. 2014).

THQ is converted into highly reactive TQ by oxidation and THQ formed by reduction of TQ. Formation of THQ
Fig. 4 Chemical structure of a TQ, b DTQ, c THQ, d thymol and e p-cymene<smiles>CC1=CC(=O)C(C(C)C)=CC1=O</smiles>

(a)<smiles>Cc1cc(O)c(C(C)C)cc1O</smiles>

(c)<smiles>CC(C)C1=CC(=O)[C@@]2(C)C(C1=O)C1C(=O)C=C(C(C)C)C(=O)[C@@]12C</smiles>

(b)<smiles>Cc1ccc(C(C)C)c(O)c1</smiles><smiles>Cc1ccc(C(C)C)cc1</smiles>

(e) 


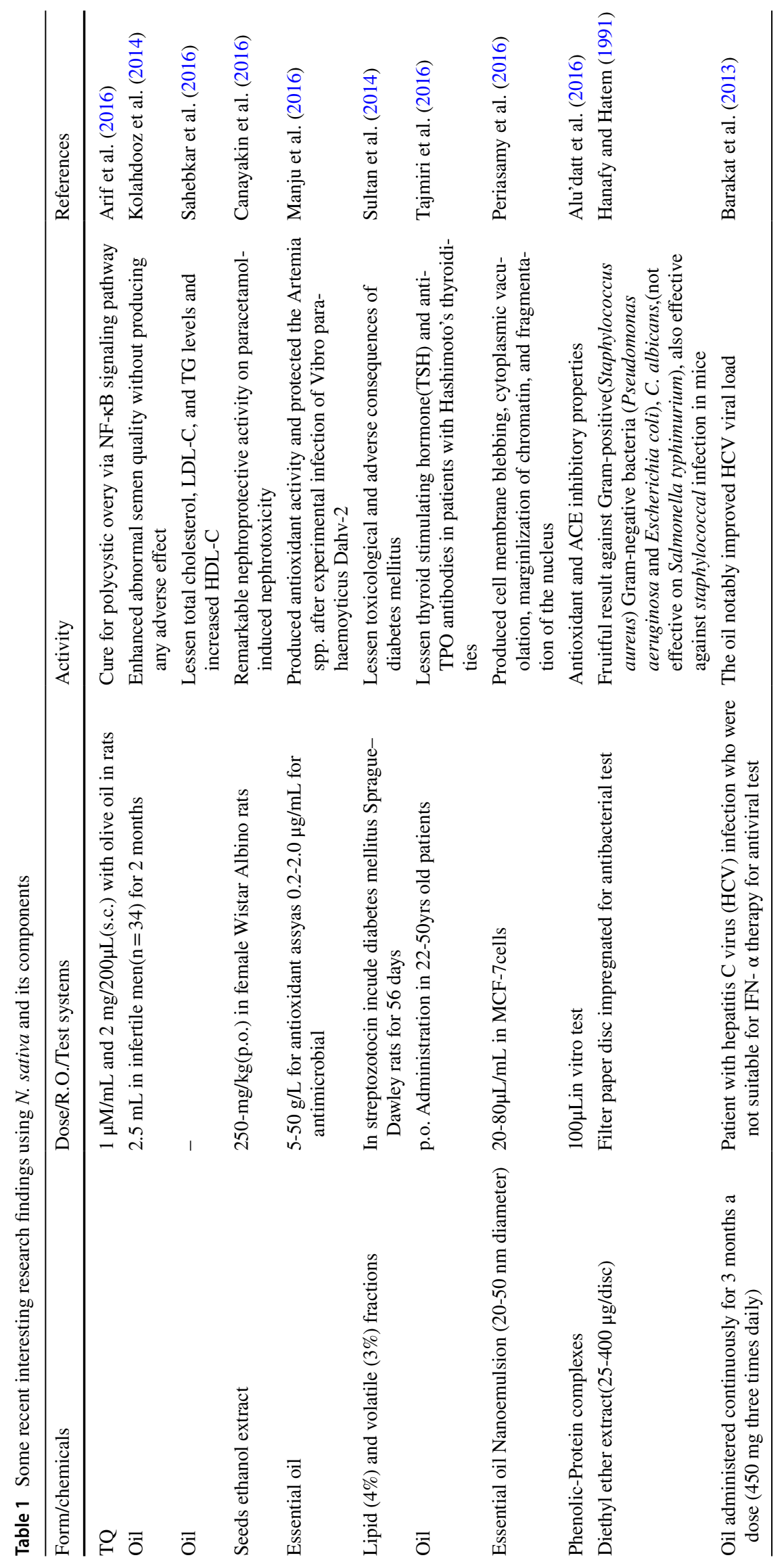




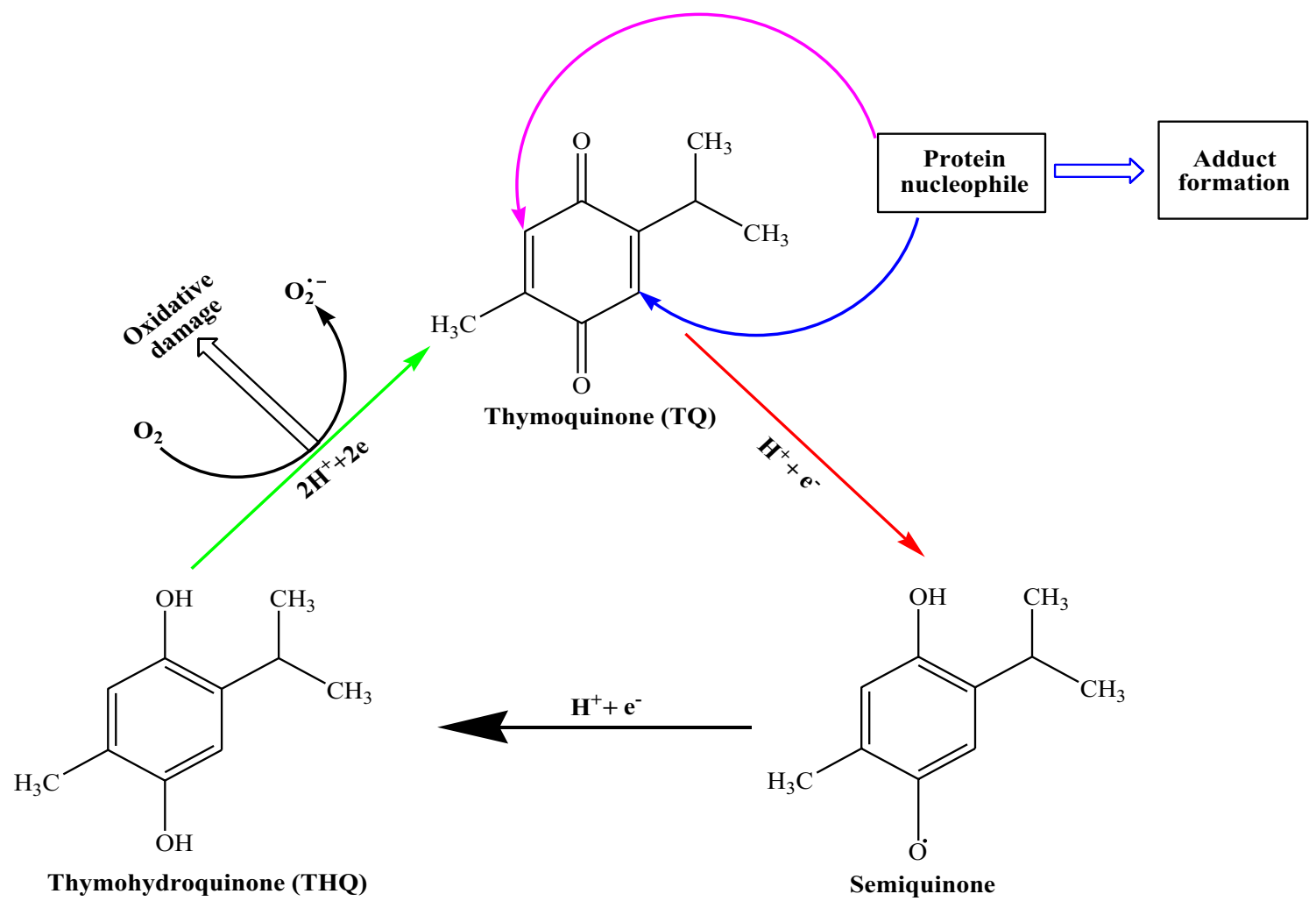

Fig. 5 Proposed reaction mechanism of TQ and THQ on viral proteins

from TQ may occur by two steps. TQ can be converted to semiquinone radical by accepting one electron and one hydrogen ion. In the same way, THQ is formed from semiquinone radical. TQs can react with viral proteins in two different ways. First, redox-cycling between TQs and the reduced form (THQs) can lead to the formation of reactive oxygen species (ROS) which can be fatal to biological events. The outcome of TQ redox-cycling would be the generation of ROS such as superoxide ion radical which can cause oxidative damage of proteins. Oxidative damage includes formation of $\mathrm{H}_{2} \mathrm{O}_{2}$ from $\mathrm{O}_{2}^{-}$which in turn produces hydroxyl radical in presence of metal ion that causes virus inactive and production of water. Second, the functional groups of peptides and proteins are those of the side chains of the constituent amino acids and the terminal amino acid residues, it would be expected that proteins could react with TQs, and such reactions do occur, although their complexity is greater than that observed for the free amino acid or related compound. TQs can alkylate a protein via a nucleophilic attack by the protein, undergoing adducts formation with the reacting protein. Characteristic reactions of TQ include the addition of nucleophilic groups to an unsaturated carbon of the TQ. Carbon carbon double bonds conjugated with electron sinks may serve as substrates for nucleophilic addition reactions. The reaction can be initiated by $\mathrm{N}, \mathrm{O}$, and S-containing nucleophilic amino acids in a protein. A proposed formation mechanism for the TQ/protein adduct follows the Michael addition (Mihara and Shibamoto 2015). The free carbon center of TQ is highly reactive center for nucleophiles of proteins' residues. As a result, the amount of adduct formation is higher than that of other reaction pathways. So the adduct formation with proteins follows the main mechanism of modifying proteins which were studied by researchers utilizing mass spectrometric approach, target enzyme activity assays, ${ }^{14} \mathrm{C}$ labeling experiments and ESI-MS approach (Kondrová et al. 2007; Zaborska et al. 2007; Fisher et al. 2007, 2011; Person et al. 2003; Hanzlik et al. 1994). Total components obtained from $N$. sativa extract i.e., TQ, THQ, DTQ, THY, and p-cymene etc. may react with more proteins and deactivation of more viruses occur as well. In human body, proteins can be converted into ammonia and carbon dioxide in a set of biochemical reactions. Protein which is taken as diet is broken down to constituent amino acids, which are then converted to carbon dioxide, water, and ammonia in the liver. In human body, enzymes in the liver metabolize toxic ammonia and carbon dioxide to nontoxic urea. Urea is the product of a series of biochemical reactions, and urea produced in the liver is transported to the kidneys and finally excreted as a waste product in urine that is presented in Fig. 6. 
Fig. 6 Cycle for the conversion of $\mathrm{NH}_{3}$ leads to urea from proteins metabolism

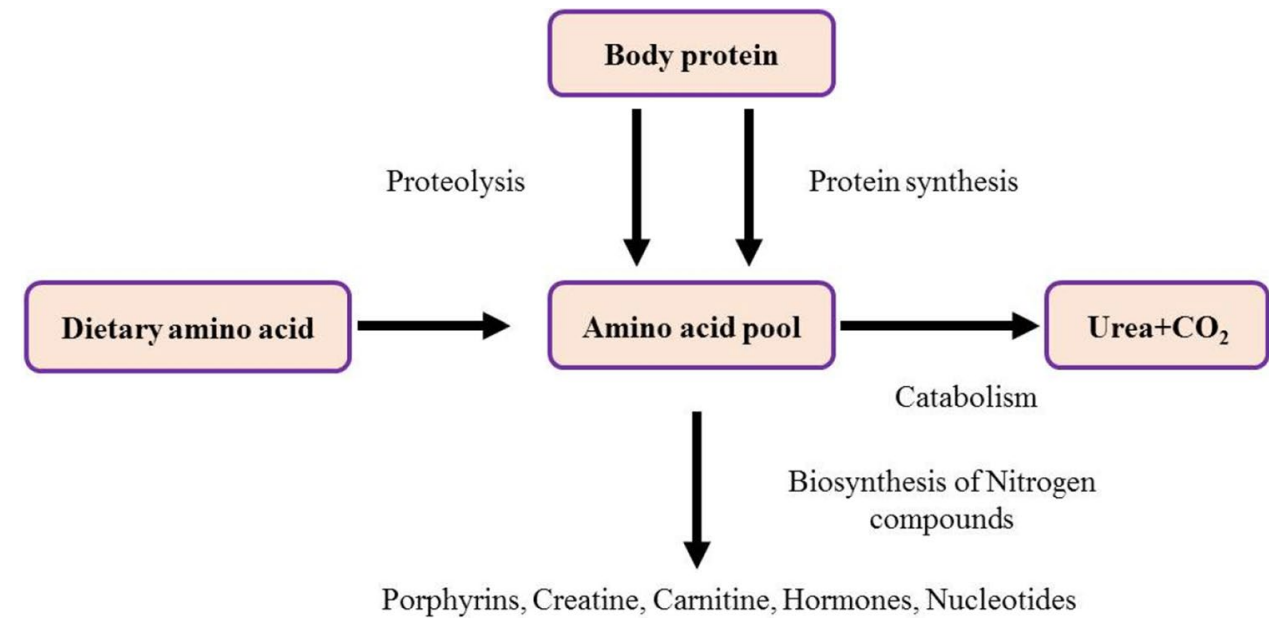

\section{Compliance with ethical standards}

This article introduces a new way of developing PVA- $N$. sativa nanofibrous membrane by electrospinning technique that show the antibacterial resistance against $S$. aureus bacteria. The morphological structure has been shown that having nanofibers with particular diameter and tiny pores. The existence of a variety of sharp, strong and weak peaks as well as crucial functional groups that correspond to $\mathrm{C}-\mathrm{H},-\mathrm{CH}_{2},-\mathrm{CH}_{3}, \mathrm{C}=\mathrm{O}, \mathrm{C}-\mathrm{O}, \mathrm{C}=\mathrm{C}$ suggesting the presence of the components of $N$. sativa have been assigned in the results of developed PVA- $N$. sativa nanofibrous membrane. Supplementary components can be added to improve the functional properties of developed sample so that it can be used for personal protective equipment (PPE) e.g. mask, globes. The proposed mechanism shows that TQ and THQ components react with viral proteins and can modify/damage the proteins. As this process occurs with natural bio-elements, it reduces the risk factor of human health. In future, there is a room for further research on components of $N$. sativa to improve the immunity of human body with proper drug delivery system against virus.

Acknowledgements We would like to thank Department of Textile Engineering and Institute of Energy Engineering, DUET, Gazipur 1707 Bangladesh for providing technical and financial support. Sincere thanks to Waffen research laboratory (WRL), Dhaka for providing the antibacterial testing facility. We also acknowledge the valuable guidelines of Professor (Supernumerary) Dr Md Nurul Islam, Department of Chemistry, DUET.

Author contributions Md Abdus Shahid: Conceptualization, Supervision, Investigation, Writing, Editing. Abdur Rahim: Conceptualization, Analysis, Writing, Editing. Mohammad Asaduzzaman Chowdhury: Conceptualization, Supervision, Analysis, Writing, Editing. Mohammod Abul Kashem: Supervision, Writing.

Funding Not applicable.
Ethical statement This article does not contain any studies with human participants or animals performed by any of the authors.

Conflict of Interest Md Abdus Shahid has no conflict of interest. Abdur Rahim has no conflict of interest. Mohammad Asaduzzaman Chowdhury has no conflict of interest. Mohammad Abul Kashem has no conflict of interest.

\section{References}

Abdullah NA, Sekak KA, Ahmad MR, Effendi TB (2014) Characteristics of electrospun PVA-Aloe vera nanofibres produced via electrospinning. In: Proceedings of the international colloquium in textile engineering, fashion, apparel and design 2014 (ICTEFAD 2014). Springer, Singapore, pp 7-11

Agarwal S, Wendorff JH, Greiner A (2008) Use of electrospinning technique for biomedical applications. Polymer 49(26):5603-5621

Ahmad A, Husain A, Mujeeb M, Khan SA, Najmi AK, Siddique NA, Anwar F (2013) A review on therapeutic potential of Nigella sativa: a miracle herb. Asian Pac J Trop Biomed 3(5):337-352

Ainane T, Askaoui Z, Elkouali M, Talbi M, Lahsasni S, Warad I, Hadda TB (2014) Chemical composition and antibacterial activity of essential oil of Nigella sativa seeds from Beni Mellal (Morocco): what is the most important part, Essential Oil or the rest of seeds. J Mater Environ Sci 5(6):2017-2020

Ali BH, Blunden G (2003) Pharmacological and toxicological properties of Nigella sativa. Phytother Res Int J Devot Pharmacol Toxicol Eval Nat Prod Deriv 17(4):299-305

Ali A, Shahid MA (2019) Polyvinyl alcohol (PVA)-Azadirachta indica (Neem) nanofibrous mat for biomedical application: formation and characterization. J Polym Environ 27(12):2933-2942

Ali A, Shahid MA, Hossain MD, Islam MN (2019) Antibacterial bilayered polyvinyl alcohol (PVA)-chitosan blend nanofibrous mat loaded with Azadirachta indica (neem) extract. Int J Biol Macromol 138:13-20

Aljabre SH, Alakloby OM, Randhawa MA (2015) Dermatological effects of Nigella sativa. J Dermatol Dermatol Surg 19(2):92-98

Al-Mufarrej SI (2014) Immune-responsiveness and performance of broiler chickens fed black cumin (Nigella sativa L.) powder. J Saudi Soc Agric Sci 13(1):75-80 
Alu'datt MH, Rababah T, Alhamad MN, Gammoh S, Ereifej K, Alodat MD, Torley PJ (2016) Antioxidant and antihypertensive properties of phenolic-protein complexes in extracted protein fractions from Nigella damascena and Nigella arvensis. Food Hydrocoll 56:84-92

Arif M, Thakur SC, Datta K (2016) Implication of thymoquinone as a remedy for polycystic ovary in rat. Pharm Biol 54(4):674-685

Armutcu F, Akyol S, Akyol O (2018) The interaction of glutathione and thymoquinone and their antioxidant properties. Electron $\mathrm{J}$ Gen Med 15(4):em59

Azeem T, Zaib-Ur-Rehman US, Asif M, Arif M, Rahman A (2014) Effect of Nigella Sativa on poultry health and production: a review. Sci Lett 2(2):76-82

Barakat EMF, El Wakeel LM, Hagag RS (2013) Effects of Nigella sativa on outcome of hepatitis C in Egypt. World J Gastroenterol WJG 19(16):2529-2536

Benkaci-Ali F, Akloul R, Boukenouche A, Pauw ED (2013) Chemical composition of the essential oil of Nigella sativa seeds extracted by microwave steam distillation. J Essential Oil Bear Plants 16(6):781-794

Canayakin D, Bayir Y, Kilic Baygutalp N, Sezen Karaoglan E, Atmaca HT, Kocak Ozgeris FB, Halici Z (2016) Paracetamol-induced nephrotoxicity and oxidative stress in rats: the protective role of Nigella sativa. Pharm Biol 54(10):2082-2091

Fisher AA, Labenski MT, Malladi S, Gokhale V, Bowen ME, Milleron RS, Lau SS (2007) Quinone electrophiles selectively adduct "electrophile binding motifs" within cytochrome c. Biochemistry 46(39): 11090-11100

Fisher AA, Labenski MT, Malladi S, Chapman JD, Bratton SB, Monks TJ, Lau SS (2011) The frequency of 1, 4-benzoquinone-lysine adducts in cytochrome c correlate with defects in apoptosome activation. Toxicol Sci 122(1):64-72

Guarino V, Ambrosio L (eds) (2018) Electrofluidodynamic technologies (EFDTs) for biomaterials and medical devices: principles and advances. Woodhead Publishing, Cambridge

Hanafy MSM, Hatem ME (1991) Studies on the antimicrobial activity of Nigella sativa seed (black cumin). J Ethnopharmacol 34(2-3):275-278

Hanzlik RP, Harriman SP, Frauenhoff MM (1994) Covalent binding of benzoquinone to reduced ribonuclease Adduct structures and stoichiometry. Chem Res Toxicol 7(2):177-184

Huang C, Wang Y, Li X, Ren L, Zhao J, Hu Y, Cheng Z (2020) Clinical features of patients infected with 2019 novel coronavirus in Wuhan, China. Lancet 395(10223):497-506

Khan MA (2018) Antimicrobial action of thymoquinone. In: Molecular and therapeutic actions of thymoquinone. Springer, Singapore, pp 57-64

Kim J, Vaughn AR, Cho C, Albu TV, Carver EA (2012) Modifications of ribonuclease A induced by p-benzoquinone. Bioorg Chem 40:92-98

Kolahdooz M, Nasri S, Modarres SZ, Kianbakht S, Huseini HF (2014) Effects of Nigella sativa L. seed oil on abnormal semen quality in infertile men: a randomized, double-blind, placebo-controlled clinical trial. Phytomedicine 21(6):901-905

Kondrová E, Stopka P, Souček P (2007) Cytochrome P450 destruction by benzene metabolites 1, 4-benzoquinone and 1, 4-hydroquinone and the formation of hydroxyl radicals in minipig liver microsomes. Toxicol In Vitro 21(4):566-575

Kundu J, Chun KS, Aruoma OI, Kundu JK (2014) Mechanistic perspectives on cancer chemoprevention/chemotherapeutic effects of thymoquinone. Mutat Res Fundam Mol Mech Mutagenesis 768:22-34

Lai CC, Shih TP, Ko WC, Tang HJ, Hsueh PR (2020) Severe acute respiratory syndrome coronavirus 2 (SARS-CoV-2) and corona virus disease-2019 (COVID-19): the epidemic and the challenges. Int J Antimicrob Agents 105924
Liu X, Lin T, Fang J, Yao G, Zhao H, Dodson M, Wang X (2010) In vivo wound healing and antibacterial performances of electrospun nanofibre membranes. J Biomed Mater Res Part A 94(2):499-508

Lodish H, Berk A, Zipursky SL, Matsudaira P, Baltimore D, Darnell J (2000) Viruses: Structure, function, and uses. In: Molecular cell biology, 4th edn. WH Freeman

Mahboubi M (2018) Natural therapeutic approach of Nigella sativa (Black seed) fixed oil in management of Sinusitis. Integr Med Res 7(1):27-32

Mahmoud YK, Abdelrazek HM (2019) Cancer: thymoquinone antioxidant/pro-oxidant effect as potential anticancer remedy. Biomed Pharmacother 115:108783

Majeed A, Muhammad Z, Ahmad H, Hayat SSS, Inayat N, Siyyar S (2020) Nigella sativa L.: uses in traditional and contemporary medicines-an overview. Acta Ecol Sin

Manju S, Malaikozhundan B, Withyachumnarnkul B, Vaseeharan B (2016) Essential oils of Nigella sativa protects Artemia from the pathogenic effect of Vibrio parahaemolyticus Dahv2. J Invertebr Pathol 136:43-49

Mansur HS, Sadahira CM, Souza AN, Mansur AA (2008) FTIR spectroscopy characterization of poly (vinyl alcohol) hydrogel with different hydrolysis degree and chemically crosslinked with glutaraldehyde. Mater Sci Eng C 28(4):539-548

Mihara S, Shibamoto T (2015) The role of flavor and fragrance chemicals in TRPA1 (transient receptor potential cation channel, member A1) activity associated with allergies. Allergy Asthma Clin Immunol 11(1):11

Mohammed IN, Babikir HE (2013) Traditional and spiritual medicine among Sudanese children with epilepsy. Sudanese J Paediatr 13(1):31

Mohammed SJ, Amin HH, Aziz SB, Sha AM, Hassan S, Aziz A, Rahman HS (2019) Structural characterization, antimicrobial activity, and in vitro cytotoxicity effect of black seed oil. Evide Based Complem Altern Med

Park M, Shin HK, Kim BS, Kim MJ, Kim IS, Park BY, Kim HY (2015) Effect of discarded keratin-based biocomposite hydrogels on the wound healing process in vivo. Mater Sci Eng C 55:88-94

Periasamy VS, Athinarayanan J, Alshatwi AA (2016) Anticancer activity of an ultrasonic nanoemulsion formulation of Nigella sativa L. essential oil on human breast cancer cells. Ultrason Sonochem 31:449-455

Person MD, Monks TJ, Lau SS (2003) An integrated approach to identifying chemically induced posttranslational modifications using comparative MALDI-MS and targeted HPLC-ESI-MS/MS. Chem Res Toxicol 16(5):598-608

Saad B, Azaizeh H, Said O (2005) Tradition and perspectives of Arab herbal medicine: a review. Evidence Based Complem Altern Med 2(4):475-479

Sahebkar A, Beccuti G, Simental-Mendía LE, Nobili V, Bo S (2016) Nigella sativa (black seed) effects on plasma lipid concentrations in humans: a systematic review and meta-analysis of randomized placebo-controlled trials. Pharmacol Res 106:37-50

Schoeman D, Fielding BC (2019) Coronavirus envelope protein: current knowledge. Virol J 16(1):69

Seebach D, Beck AK, Bierbaum DJ (2004) The world of $\beta$-and $\gamma$-peptides comprised of homologated proteinogenic amino acids and other components. Chem Biodivers 1(8):1111-1239

Shahid MA, Ali A, Uddin MN, Miah S, Islam SM, Mohebbullah M, Jamal MSI (2020) Antibacterial wound dressing electrospun nanofibrous material from polyvinyl alcohol, honey and Curcumin longa extract. J Ind Text 1528083720904379

Shereen MA, Khan S, Kazmi A, Bashir N, Siddique R (2020) COVID19 infection: origin, transmission, and characteristics of human coronaviruses. J Adv Res 
Sultan MT, Butt MS, Karim R, Ahmad AN, Suleria HAR, Saddique MS (2014) Toxicological and safety evaluation of Nigella sativa lipid and volatile fractions in streptozotocin induced diabetes mellitus. Asian Pac J Trop Dis 4:S693-S697

Tajmiri S, Farhangi MA, Dehghan P (2016) Nigella sativa treatment and serum concentrations of thyroid hormones, transforming growth factor $\beta$ (TGF- $\beta$ ) and interleukin 23 (IL-23) in patients with Hashimoto's Thyroiditis. Eur J Integr Med 8(4):576-580

Tohumiari TTYVT (2017) Quantitative analysis of thymoquinone in Nigella sativa L. (Black Cumin) seeds and commercial seed oils and seed oil capsules from Turkey. J Fac Pharm Ankara Ankara Ecz Fak Derg 41(1):34-41

Vaughn AR, Redman CB, Kang SM, Kim J (2013) Biological implications of 2-chlorocyclohexa-2, 5-diene-1, 4-dione toward ribonuclease A. Adv Biosci Biotech 4:22-28

Venugopal JR, Low S, Choon AT, Kumar AB, Ramakrishna S (2008) Nanobioengineered electrospun composite nanofibers and osteoblasts for bone regeneration. Artif Organs 32(5):388-397
Yang Y, Zhu X, Cui W, Li X, Jin Y (2009) Electrospun composite mats of poly [(D, L-lactide)-co-glycolide] and collagen with high porosity as potential scaffolds for skin tissue engineering. Macromol Mater Eng 294(9):611-619

Zaborska W, Krajewska B, Kot M, Karcz W (2007) Quinone-induced inhibition of urease: elucidation of its mechanisms by probing thiol groups of the enzyme. Bioorg Chem 35(3):233-242

Publisher's Note Springer Nature remains neutral with regard to jurisdictional claims in published maps and institutional affiliations. 